\title{
E-Readiness Competencies of MSU-Naawan Professors and Students' Perceptions on Online Classes amidst COVID-19
}

\author{
Fernan Q. Abragan \\ Ohttps://orcid.org/0000-0002-6647-575X \\ Mindanao State University at Naawan, Philippines \\ *e-mail: fernan.abragan@gmail.com
}

\begin{abstract}
Article Information
Received: December 04, 2020

Revised: December 04, 2020

Accepted: December 04, 2020

Online: March 01, 2021
\end{abstract}

\section{Keywords}

e-readiness, perception, online

\begin{abstract}
The purpose of this study was to identify the professors' ereadiness competencies in implementing online classes in terms of course design, course communication, time management, and technical competence. Also, it aimed to determine the students' perception towards the online class in terms of instructional design and delivery on students, teacher roles on students, and class organization and format. Pure descriptive analysis was used in analyzing the data, such as mean and percentage distribution. Both adapted and adopted survey questionnaires were used to address this research's problem, and these were distributed to the respondents either via online and phone call. Results showed that the senior high school department professors were good enough to use online platforms with an overall mean of 1.76, which implies that most of them are technically sound. Students have agreed that their professors are satisfied with instructional design and delivery, teacher roles, and class organization and format. The overall mean of 3.60 of students' perception towards online class implies that students have perceived their teacher's teaching way amidst pandemics is still promoting students' desire to learn, which engaged them to become more interactive in various activities. Because there are observable few numbers that can be seen in the results indicating that the teachers are not proficient enough in digital literacy, it is highly recommended to get the respondents' demographic profile in terms of age and training attended about computer literacy. Also, recommended that the professors' e-readiness be correlated to students' perception of the online class.
\end{abstract}

\section{INTRODUCTION}

COVID-19 has posed a significant threat to the global education system. Rethinking alternative classes for continuing education is the central issue for coping with the new-normal system. In this regime of the global lockdown of educational institutions, technologically advanced countries are equipped with all the tools required for online education, whereas developing countries can implement online education in full-fledge. So, the countries are dealing with how they can have required learning amid this prolonged lockdown scenario. As a concern, drastic changes in the educational system are required to make the education system vivid. Technology and ICT-based education, mainly online 
education, is the most excellent solution to prominent trouble (Ramij et al., 2020). Several studies were conducted regarding the readiness of teachers in online learning and teaching. In turkey, one study revealed that teachers' overall technology readiness level was moderate. There are no significant differences in technology readiness across age and the teachers' subject area but a significant difference between technology readiness and gender (Summak et al., 2010). The Department of Education's advocacy on computerization may contribute to the teachers' attitude in online education, as one study conducted that organizational readiness factors have the most critical effect on e-Learning outcomes. One study also revealed that teachers' motivation and training are the most critical factor in e-learning (M.-L. Hung, 2016). The level of online instructor e-readiness in a higher education context has been evaluated based on their technology skills, lifestyle, and pedagogical training using an ELS (Darab et al., 2011; Holsapple et al., 2006; Keramati et al., 2011). Since online instructors' attitudes towards the ELS have focused on opinions and perceptions of its performance, their level of e-readiness can influence their use and application of technology tools needed to assist online learners and is reflected in successful course outcomes and user satisfaction (W.-H. Hung et al., 2014; Larbi et al., 2012). There is a need to further examine the influence of technical factors on online instructors during the phases of delivering a course apart from evaluating the technology itself (McGill et al., 2011; Motaghian et al., 2013; Panda et al., 2007). Online education has moved into higher education, with new programs being added continuously about the technology-based adjustments in the new normal. Students are compelled to keep abreast with online learning environments being skilled in the new platform environments. Students' acceptance of e-learning was positive, and mobile technology was the preferred medium for this. However, a persistent unfamiliarity towards e-learning tools compared to social media was noticed. Smith et al. (2019) concluded that most of the learners' preferred online learning mode to other types provides more flexibility in learning, time management and offers more courses worldwide. Azis et al. (2019) established that learners' experience on e-learning significantly influences the learning process's effectiveness and achieves indirect learning outcomes through the learning process.

A study conducted by Bradley et al. on graduate students' perceptions of online classes was conducted to gain insights into graduate students' perceptions regarding online learning. Two-hundred forty-nine (249) graduate students were surveyed to identify positive components that led to their satisfaction and perceived challenges that inhibited it. Findings from the study indicated that interaction between students and the instructor significantly impacted their satisfaction. Given the importance and the need to assess the teachers' readiness and students' perception towards online classes amidst COVID-19, the following research questions are addressed:

1. The professors' e-readiness competencies in implementing online classes a. course design; $b$. course communication; c. time management; and d. technical competence?

2. The students' perceptions towards the online class regarding a. instructional design and delivery on students; b. teacher roles on students; and c. class organization and format?

\section{METHODS}

This study employed a quantitative research design using descriptive analysis to identify the professors' e-readiness competencies and determine the students' perception towards the online class. Quantitatively, both adopted and adapted survey questionnaires were used in the study to address the research problems. The study respondents were the faculty members and officially enrolled students of senior high school this first semester, S.Y. 2020-2021, under the College of Education and Social Sciences of the Mindanao State University at Naawan Naawan Misamis Oriental. Average weighted mean was used to determine and interpret the e-readiness competencies of MSU-Naawan Professors and students' perceptions of online classes.

Table 1. Mean interval score and interpretation on the e-readiness competencies of MSU- Naawan Professors in the online class

\begin{tabular}{ccc}
\hline Scale & Range & Interpretation \\
\hline 3 & $2.32-3.00$ & Ready
\end{tabular}




\begin{tabular}{ccc}
\hline Scale & Range & Interpretation \\
\hline 2 & $1.66-2.31$ & Moderately Ready \\
1 & $1.00-1.65$ & Not Ready \\
\hline
\end{tabular}

Table 2. Mean interval score and interpretation of students' perception towards online class

\begin{tabular}{ccc}
\hline Scale & Range & Interpretation \\
\hline 5 & $4.20-5.00$ & Certainly Positive \\
4 & $3.40-4.19$ & Rather Positive \\
3 & $2.60-3.39$ & Neither \\
2 & $1.80-2.59$ & Rather Negative \\
1 & $1.00-1.79$ & Certainly Negative \\
\hline
\end{tabular}

\section{RESULTS}

Professors' e-readiness competencies in implementing online class

Table 3 shows the mean results and interpretation of the professors' e-readiness competencies in implementing online classes. Based on the presentation, it can be gleaned that among the five factors such as course design, course communication, time management, and technical competence, almost all the professors considered themselves as moderately ready to facilitate online classes with an overall mean of 1.76 .

Table 3. Mean result and interpretation of the e-readiness competencies of MSU-Naawan Professors in an online class

\begin{tabular}{lcl}
\hline \multicolumn{1}{c}{ Items } & Mean & Interpretation \\
\hline Course Design & 1.68 & Moderately Ready \\
Course Communication & 1.85 & Moderately Ready \\
Time Management & 1.79 & Moderately Ready \\
Technical Competence & 1.72 & Moderately Ready \\
\hline Overall Mean & $\mathbf{1 . 7 6}$ & Moderately Ready \\
\hline
\end{tabular}

\section{Students' perception of online class}

Table 4 displays the mean results and interpretation of students' perception of an online class in terms of instructional design and delivery effects on students' satisfaction and class organization and format. It can be observed from the table that the students' overall perception mean is 3.60, which means that they have a positive perception towards their professors in an online class rather.

Table 4. Mean result and interpretation of students' perception towards online class

\begin{tabular}{lcl}
\hline \multicolumn{1}{c}{ Items } & Mean & Interpretation \\
\hline $\begin{array}{l}\text { Effects of Instructional Design and } \\
\text { Delivery on Students' Satisfaction }\end{array}$ & 3.53 & Rather Positive \\
$\begin{array}{l}\text { Effects of Teacher Roles on Students' } \\
\text { Satisfaction }\end{array}$ & 3.47 & Rather Positive \\
\begin{tabular}{l} 
Class Organization and Format \\
\hline
\end{tabular} & 3.35 & Neither \\
\hline
\end{tabular}




\begin{tabular}{lccl}
\hline & Items & Mean & Interpretation \\
\hline Overall Mean & 3.60 & Rather Positive \\
\hline
\end{tabular}

\section{DISCUSSION}

\section{Professors' e-readiness competencies in implementing online class}

As presented in table 3, it can be inferred that professors are good enough at facilitating or handling online classes. It might be that during these dire times, faculty members of the institution were provided with free training and workshops as to how to handle online class platforms. Besides, even before the pandemic time, most of the faculty members are already using an asynchronous class type when they are not around. For the course design, it can be deduced that professors are good enough in making a clear objective so that their students can be guided as to what they would be expecting at the end of the course time frame. It also includes incorporating course materials such as written documents and supplementary videos to understand the concept further.

Moreover, professors' way of communicating with their students can be seen from the results, that most of them do web-video conferencing and asynchronous means of sending communications to students designed for instruction, orientation, and discussion. As to time management, it can be observed that professors can use features in the learning management system since activity deadlines can be set in the particular online web as to when the students will submit the assigned tasks. It further helps the professors identify students who submit their respective tasks on time and late.

Lastly, with regards to technical competence, professors are prepared since online platforms have been partly part of their teaching journey because even before they have been using online platforms, it is just that some refused to learn it especially old-aged ones. As to the degree of professors' e-readiness in an online class, most of them are technically sound. Thus, this relates to Anderson's Online Learning Model, which examines the characteristics and facilities that the Internet provides regarding each of the four lenses: community-centeredness, knowledge-centeredness, learner-centeredness, and assessment-centeredness (Anderson, 2008). With the same study conducted by (Martin et al., 2019), which aimed to measure the faculty readiness to teach online, MANOVA showed significant differences in gender, years of teaching online, and delivery method for faculty perceptions of the importance of online teaching competencies. Significant differences were also noted in years of teaching online and delivery methods concerning teaching online.

\section{Students' perception of online class}

The result in table 4 can be interpreted as having agreed that they are satisfied by their professors in terms of instructional design and delivery, teacher roles, and class organization and format. This further implies that students have perceived their teacher's teaching way amidst pandemic is still promoting students' desire to learn, which engaged them to become more interactive in various activities. Thus, it can be concluded that the professors have employed and established their rapport towards their students and sustained their roles being facilitators of learning despite the new classroom environment. Moreover, the result shows a good indication that the course activities are transparent, guiding, and helping the students attain specific learning goals in every concept lesson. Findings from the study indicated that interaction between students and the instructor significantly impacted their satisfaction.

Other challenges identified were sufficient learner support linked to campus resources and the need for varying instructional design and delivery to facilitate students' desire to learn. In contrast, students were delighted with the clarity and organization of instruction using sufficient resources. The instructor's role was vitally important to students' satisfaction (Fedynich, 2013). Results can be attributed to the Information processing learning theory, which is a variation of cognitivism that views the human mind as a system that processes information according to logical rules. The mind is frequently compared to a computer that follows a set of rules or programs.

Research using this perspective attempts to describe and explain changes in the mental processes and strategies that lead to greater cognitive competence as children develop. Atkinson et al. (1968) is generally credited with proposing the first information processing model that deals with how students acquire, encode, store (in short-term or long-term memory), and retrieve information. 


\section{CONCLUSION}

Professor's e-readiness in teaching an online class is good, which only means that faculty members of the Mindanao State University at Naawan are equipped with enough digital or computer skills in handling asynchronous and synchronous classes. Since professors' e-readiness are found out as technically sound, students perceived that they are satisfied with the way how their professors adapted the new typical learning environment in terms of delivery of instruction, their roles being the facilitator of learning, and most of all, the class management and the organization of the subject matter.

Due to time constraints, only grade 12 students from sections STEM A, STEM B, and STEM C and professors teaching grade 12 students were asked to participate in the study for the first semester of the school year 2020-2021. Data for the faculty responses focused only on the e-competencies such as course design, course communication, time management, and technical competence since the time frame period is limited. Thus, other factors, such as faculty profiling that may affect the e-literacy of the faculty members, were not included anymore. Data for the students' responses were restricted to three factors: instructional design and delivery on students, teacher roles on students, and class organization and format.

The quantitative and qualitative nature of collecting the data can be both employed in this study. However, due to the particular time, qualitative data was only collected from the respondents. Because there are observable few numbers that can be seen in the results indicating that the teachers are not proficient enough in digital literacy, it is highly recommended to get the respondents' demographic profile in terms of age and training attended about computer literacy. It is also recommended that the professors' e-readiness be correlated to students' perception towards online class and teachers/ way of teaching in the new normal.

\section{ACKNOWLEDGMENT}

The author of this study would like to express his utmost and deepest thanks to the following individuals who, in one way, helped and made it possible towards the completion of the study. To the Dean of the College of Education and Social Science, all the support and motivation superbly extended, which helped the author ease his uncertainties. This study would never be completed without the senior high school faculty and senior high school students' participation for sparing their short time, answering honestly and legibly the questionnaire.

\section{REFERENCES}

Adams, J., Ngampornchai, A., (2016). Students' Acceptance and Readiness for E-learning in Northeastern Thailand, International Journal of Educational Technology in Higher Education, 13(34), 1-13. https://doi.org/10.1186/s41239-016-0034-x

Anderson, T. (2008). The Theory and Practice of Online Learning. Athabasca University Press. Retrieved from http://biblioteca.ucv.cl/site/colecciones/manuales u/99Z Anderson 2008Theory and Practice of Online Learning.pdf

Atkinson, R. C., \& Shiffrin, R. M. (1968). Human Memory: A Proposed System and its Control Processes, in W. K. Estes and G. H. Bower in K. W. Spence \& J. T. Spence (Eds.), Psychology of Learning and Motivation, 2, pp. 89-195). Academic Press. https://doi.org/10.1016/S00797421(08)60422-3

Azis, Y. M., Suharyati, H., \& Susanti, S. (2019). Student's Experience of E-Learning, Learning Process and Perceived Learning Outcomes In Economic Math Course. JHSS Journal of Humanities and Social Studies), 3(2), 67-71. https://doi.org/10.33751/ihss.v3i2.1458

Bawane, J., and Spector, J. M. (2009). Prioritization of Online Instructor Roles: Implications for Competency-Based Teacher Education Programs. Distance Education, 30(3), 383-397. Retrieved from https://www.researchgate.net/publication/233341885 Prioritization of online instructor $r$ oles Implications for competency-based teacher education programs 
Darab, B., \& Montazer, Gh. A. (2011). An eclectic model for assessing e-learning readiness in the Iranian universities. Computers \& Education, 56(3), 900-910. https://doi.org/10.1016/j.compedu.2010.11.002

David, R., Pellini, A., Jordan, K., and Phillips, T. (2020). Education during the COVID-19 Crisis Opportunities and Constraints of Using EdTech in Low-Income Countries, Policy Brief, April 2020, Retrieved from https://edtechhub.org/wp-content/uploads/2020/04/educationduring-covid-19-crisis.pdf

Easton, S. S. (2003). Clarifying the Instructor's Role in Online Distance Learning. Communication Education, 52(2), 87-105. Retrieved from https://www.tandfonline.com/doi/abs/10.1080/03634520302470

Fedynich, L. V. (2013). Teaching beyond the Classroom Walls: The Pros and Cons of Cyber Learning. Journal of Instructional Pedagogies, 13. Retrieved from https://eric.ed.gov/?id=EJ1060090

Holsapple, C. W., \& Lee-Post, A. (2006). Defining, Assessing, and Promoting E-Learning Success: An Information Systems Perspective*. Decision Sciences Journal of Innovative Education, 4(1), 6785. https://doi.org/10.1111/j.1540-4609.2006.00102.x

Hung, M.-L. (2016). Teacher readiness for online learning: Scale development and teacher perceptions. Computers \& Education, 94, 120-133. https://doi.org/10.1016/j.compedu.2015.11.012

Hung, W.-H., Chang, L.-M., Lin, C.-P., \& Hsiao, C.-H. (2014). E-readiness of website acceptance and implementation in SMEs. Computers in Human Behavior, 40, 44-55. https://doi.org/10.1016/j.chb.2014.07.046

Keramati, A., Afshari-Mofrad, M., \& Kamrani, A. (2011). The role of readiness factors in E-learning outcomes: An empirical study. Computers \& Education, 57(3), 1919-1929.

https://doi.org/10.1016/i.compedu.2011.04.005

Kim, J., Kwon, Y., \& Cho, D. (2011). Investigating Factors that Influence Social-Presence and Learning Outcomes in Distance Higher Education. Computers and Education, 57(2), 1512-1520.

Retrieved from

https://www.researchgate.net/publication/220141008 The role of readiness factors in Elearning outcomes An empirical study

Ko, S., \& Rossen, S. (2017). Teaching Online: A practical guide. Oxon: Routledge. Retrieved from https://www.routledge.com/Teaching-Online-A-Practical-Guide/Ko-

Rossen/p/book/9780415832434

Kumar, D. (2010). Pros and Cons of Online Education. Manuscript, North Carolina State University. Retrieved from https://www.ies.ncsu.edu/resources/white-papers/pros-and-cons-of-onlineeducation/

Larbi-Apau, J. A., \& Moseley, J. L. (2012). Computer Attitude of Teaching Faculty: Implications for Technology-Based Performance in Higher Education. Journal of Information Technology Education: Research, 11(1), 221-233. Retrieved from http://www.jite.org/documents/Vol11/JITEv11p221-233Larbi1120.pdf

Martin, F., Budhrani, K., \& Wang, C. (2019). Examining Faculty Perception of Their Readiness to Teach Online. Online Learning, 23(3), 97-119. Retrieved from https://files.eric.ed.gov/fulltext/EJ1228799.pdf

McGill, T., Klobas, J., \& Renzi, S. (2011). LMS Use and Instructor Performance: The Role of TaskTechnology Fit. International Journal on E-Learning, 10(1), 43-62. Retrieved from https://researchrepository.murdoch.edu.au/id/eprint/12296/1/LMS Use and Instructor Pe rformance.pdf 
Motaghian, H., Hassanzadeh, A., \& Moghadam, D. K. (2013). Factors affecting university instructors' adoption of web-based learning systems: Case study of Iran. Computers \& Education, 61, 158167. https://doi.org/10.1016/i.compedu.2012.09.016

Panda, S., \& Mishra, S. (2007). E-Learning in a Mega Open University: Faculty attitude, barriers and motivators. Educational Media International, 44(4), 323-338. https://doi.org/10.1080/09523980701680854

Pagliari, L., Batts, D., \& McFadden, C. (2009). Desired Versus Actual Training for Online Instructors in Community Colleges. Retrieved from http://thescholarship.ecu.edu/handle/10342/2176

Ramij, M. G., \& Sultana, A. (2020). Preparedness of Online Classes in Developing Countries amid COVID-19 Outbreak: A Perspective from Bangladesh (SSRN Scholarly Paper ID 3638718). Social Science Research Network. Retrieved from https://doi.org/10.2139/ssrn.3638718

Smith, C., Hoderi, M., \& Mcdermott, W. (2019). A Preliminary Study of Students Perception and Learning from different delivery methods, Academy of Educational Leadership Journal, 23(2), Retrieved from https://www.abacademies.org/articles/a-preliminary-studyof- studentsperception-and-learning-from-different-delivery-methods-8235.html

Sorcinelli, M. D., and Austin, A. E. (2006). Developing Faculty for New Roles and Changing Expectations. Effective Practices for Academic Leaders, 1(11), 1-16. Retrieved from https://lib.uwaterloo.ca/edocs/documents/EFFECTIVE PRACTICES JOURNALS/STYLUS SPE P111/STYLUS SPEP 1 11/1GW080L9N3TKKCA1.pdf

Sultana, A. and Ramiz, Md., (2020). Preparedness of Online Classes in Developing Countries Amid Covid19 Outbreak: A Perspective from Bangladesh. Department of Banking and Insurance, University of Dhaka. Retrieved from https://zenodo.org/record/3978758

Summak, M. S., Bağlıbel, M., \& Samancıŏ̆lu, M. (2010). Technology readiness of primary school teachers: A case study in Turkey. Procedia - Social and Behavioral Sciences, 2(2), 2671-2675. https://doi.org/10.1016/j.sbspro.2010.03.393 